\title{
NOTE
}

\section{Quantification of Mnemiopsis Ieidyi (Ctenophora, Lobata) from formalin-preserved plankton samples}

\author{
Jennifer E. Purcell
}

Horn Point Environmental Laboratories, PO Box 775, Cambridge, Maryland 21613, USA

\begin{abstract}
Lobate ctenophores were thought to be impossible to quantify using standard plankton collection and preservation techniques. I show that the tentacle bulbs of the lobate species Mnemiopsis leidyi provide a direct measure of numbers and sizes of the ctenophores in formalin-preserved plankton samples. The tentacle bulbs persist intact after preservation in $5 \%$ formaldehyde solution for at least 9 mo. Bulb lengths of live and preserved specimens were closely correlated with ctenophore wet weights. This method is more accurate and convenient than measures of abundance previously used for $M$. leidyi, and it may be applicable to other species of ctenophores.
\end{abstract}

Ecological studies of ctenophores, other than a few species of cydippids (i.e. Pleurobrachia spp.), have been hampered because of the difficulty in sampling them quantitatively. Standard plankton collection and preservation methods cause the destruction of lobate ctenophores in the class Tentaculata. This has led to special techniques of collection (Harbison et al. 1978) and preservation (Adams et al. 1976) that are very labor intensive.

Lobate ctenophores in the genus Mnemiopsis form conspicuous population blooms during spring and summer in estuaries of the eastern United States. These ctenophores are so abundant that methods have been developed to exclude them from plankton nets and to dissolve them if collected (Heinle 1965 and Burrell \& Van Engel 1970, respectively). The most common method of measuring the abundance of Mnemiopsis spp. ctenophores has been to measure their total live volume from plankton tows (Table 1). Total volumes have been converted to approximate numbers from size measurements of the ctenophores (Table 1). Alternatively, live ctenophores have been counted and measured immediately following plankton tows (Table 1). This method is extremely tedious, and potentially inaccurate for small ctenophores. Le Blanc \& Straw (1972) and Kremer \& Nixon (1976) used luminescent flashes of the ctenophores to measure abundance.
In the present study, I show that tentacle bulb length increases directly with size (wet weight) in Mnemiopsis leidyi. Metamorphosis from the cydippid larva to the adult form in lobate ctenophores involves disappearance of the tentacle sheaths, reduction of the tentacles, and elongation of the tentacular canals and bulbs (bases) as the tentacles shift orally in position (Hyman 1940). These structures remain after preservation in $5 \%$ formaldehyde solution, and can be used to quantify the abundance and biomass of this lobate ctenophore species.

Table 1. Studies in which measures of biomass, size, and abundance of Mnemiopsis spp. ctenophores were made. All data were from live specimens from net tows

\begin{tabular}{|c|c|c|c|}
\hline & $\begin{array}{l}\text { Volume } \\
\text { (m]) }\end{array}$ & $\begin{array}{l}\text { Length } \\
(\mathrm{mm})\end{array}$ & Number \\
\hline Nelson 1925 & $\times$ & & $\times$ \\
\hline Zeigenfuss \& Cronin 1958 & $x$ & & \\
\hline Herman et al. 1967,1968 & $x^{a}$ & & \\
\hline Burrell 1968 & $x$ & $x$ & \\
\hline Miller 1970 & $x$ & $x^{b}$ & $x$ \\
\hline Miller \& Williams 1972 & $x^{c}$ & & \\
\hline Miller 1974 & $x$ & $x^{b}$ & $x$ \\
\hline Heinle 1974 & $x^{d}$ & & \\
\hline Reeve \& Baker 1975 & $x$ & $x^{b}$ & $x$ \\
\hline Burrell \& Van Engel 1976 & $x$ & $\times$ & \\
\hline Kremer \& Nixon 1976 & $x$ & $x$ & $x$ \\
\hline Kremer 1976 & $x^{e}$ & & \\
\hline Kremer 1979 & $x^{e}$ & & \\
\hline Mountford 1980 & & & $x$ \\
\hline Lonsdale 1981 & $x$ & & \\
\hline Deason 1982 & $x$ & $x^{b}$ & $x$ \\
\hline Deason \& Smayda 1982 & & $x$ & $x$ \\
\hline Feigenbaum \& Kelly 1984 & $x$ & & \\
\hline \multicolumn{4}{|c|}{$\begin{array}{l}\text { Total volume of ctenophores and cnidarians. Data in } 1968 \\
\text { are } 1000 \times \text { too large; }{ }^{b} \text { Separation of size classes by sieves; } \\
{ }^{c} \text { From Herman et al. 1968; }{ }^{d} \text { From Herman et al. } 1967 \text {; } \\
\text { e From Kremer \& Nixon 1976 }\end{array}$} \\
\hline
\end{tabular}


Materials and Methods. Ctenophores Mnemiopsis leidyi were collected individually from the Choptank River subestuary of the Chesapeake Bay, USA, in August 1987. The lengths of both tentacle bulbs in each living ctenophore were measured using a dissecting microscope with ocular micrometer. Live ctenophore length, displacement volume, and wet weight were measured. Wet weight, measured with an electronic balance, was most accurate and is reported here. The ctenophores were preserved individually in $5 \%$ formaldehyde solution, and the lengths of the tentacle bulbs measured after 5 mo.

Plankton tows were made using a $1 \mathrm{~m}$ diameter net with flow meter. The net was made from $1.6 \mathrm{~mm}$ soft nylon mesh and had a bag cod end in order to minimize damage to the ctenophores during collection. Double oblique tows were made at 0 to $10 \mathrm{~m}$ depth at 09:00 $\mathrm{h}$ in mid-channel in Chesapeake Bay. Ctenophores were separated from the samples using a plastic colander and a $1 \mathrm{~mm}$ mesh sieve. Total live volume of the

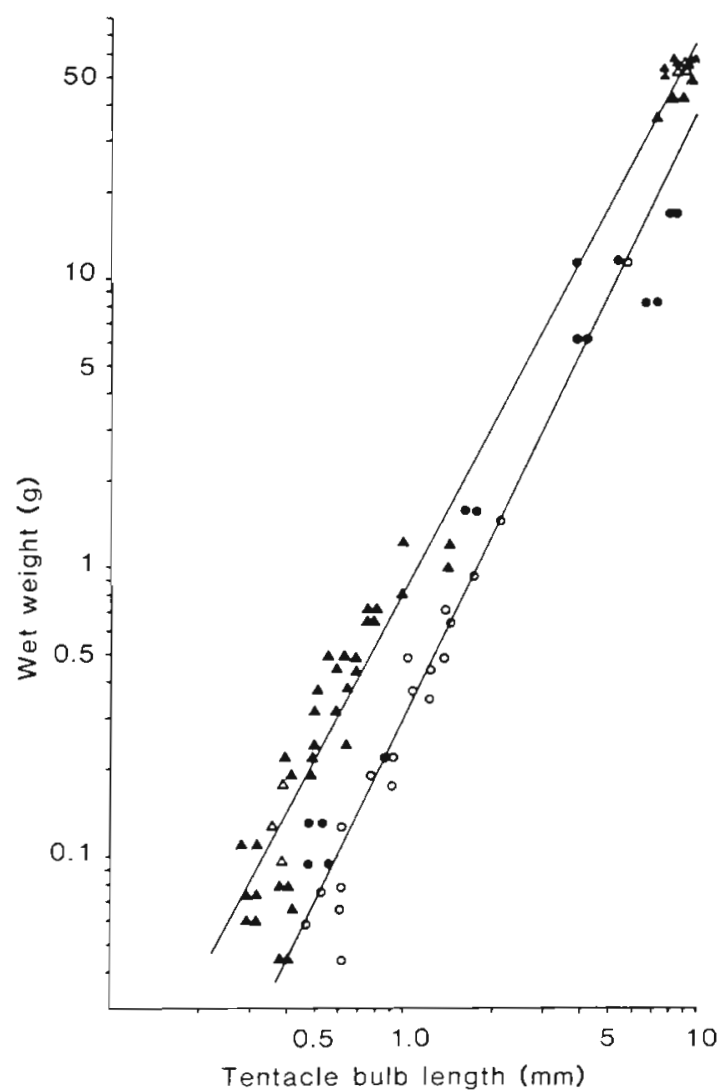

Fig. 1. Mnemiopsis leidyi. Relations of tentacle bulb length to wet weight. Circles: living specimens; triangles: specimens preserved in formalin for 5 mo. Open symbols indicate 2 bulbs of the same length in 1 ctenophore. Closed symbols represent 1 bulb. In specimens of $>50 \mathrm{~g}$ wet weight, 8 bulbs at 8 to $9 \mathrm{~mm}$ and 16 buibs at 9 to $10 \mathrm{~mm}$ preserved length were not drawn on the figure because of symbol overlap. The regressions, which included all data points, are given in the text ctenophores was measured in graduated cylinders. All ctenophores were preserved by adding full-strength ( $37 \%$ ) formalin to create a $5 \%$ final solution. The tentacle bulbs in these samples were counted and measured after 5 and 7 mo.

Results. The tentacle apparatus was readily apparent in living and preserved specimens of Mnemiopsis leidyi. It was heart-shaped in small ctenophores, and very elongate with the tentacle at one end in large ctenophores. In living ctenophores, tentacle bulb length in millimeters $(x)$ was related to wet weight in grams ( $y$ ) according to the equation $y=0.284 x^{2.108}(n=$ 55; $r=0.98$ ) (Fig. 1). Measurements of the 2 tentacle bulbs were usually the same in a living ctenophore (Fig. 1); however, in preserved specimens, bulbs differed by a mean of $10.3 \% \pm 9.3 \mathrm{SD}$.

Preservation in $5 \%$ formalin caused the ctenophores to break apart, but the tentacle apparatus always remained intact. The tentacle bulbs did not lose their orange coloration during 9 mo of storage in $5 \%$ formalin. Tentacle bulb length decreased a mean of $42.8 \%$ $\pm 9.8 \mathrm{SD}$ during $5 \mathrm{mo}$ in storage. At $5 \mathrm{mo}$, preserved tentacle bulb length $(x)$ was related to live wet weight $(y)$ according to the equation $y=0.810 x^{1.913}(n=67$; $r=0.99$ ) (Fig. 1). After 9 mo storage, bulb lengths had decreased a mean of $47.9 \% \pm 9.6 \mathrm{SD}$ from live bulb lengths, indicating that an additional $5 \%$ shrinkage occurred between 5 and 9 mo.

Tentacle bulbs were used to quantify ctenophore abundance from formalin-preserved plankton tows made on 2 dates in 1987. On 4 June, water temperature was $23.0^{\circ} \mathrm{C}$ and salinity was $12.8 \%$ at the surface. Hydromedusae Nemopsis bachei in the sample $(425 \mathrm{ml}$ volume) could be separated only by hand from the ctenophores $(90 \mathrm{ml}$ volume). Ctenophore live volume

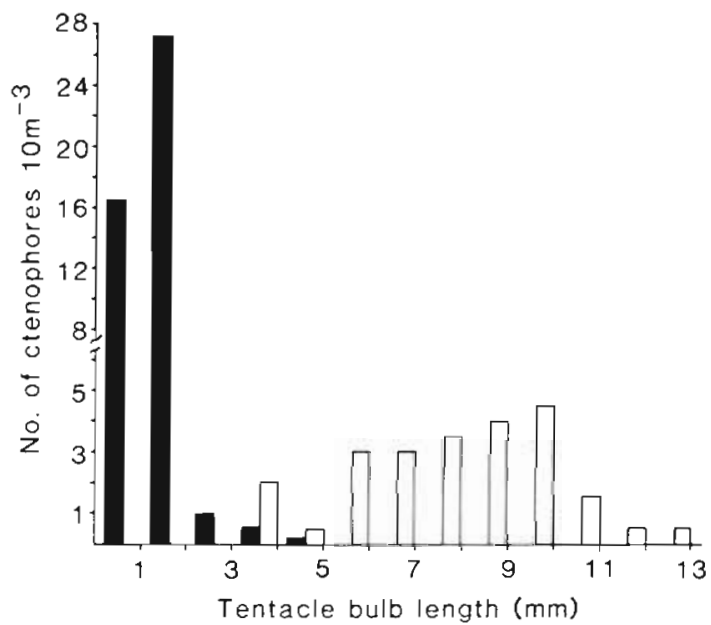

Fig. 2. Mnemiopsis leidyi. Abundances and size distributions based on tentacle bulbs in formalin-preserved plankton tows Black bars: 4 June 1987; open bars: 13 August 1987. Note that scale changes above 6 ctenophores $\mathrm{m}^{-3}$ 
was about $0.6 \mathrm{ml} \mathrm{m} \mathrm{m}^{-3}$. Preserved in the sample were 257 hydromedusae and 756 ctenophores (1512 tentacle bulbs), equivalent to 4.6 ctenophores $\mathrm{m}^{-3}$. The size distribution of tentacle bulbs showed that very small ctenophores predominated on that date (Fig. 2).

On 13 August, water temperature was $26.3^{\circ} \mathrm{C}$ and salinity was $15.1 \%$ at the surface. The sample contained $10 \mathrm{ml}$ of scyphomedusae Chrysaora quinquecircha, and $6365 \mathrm{ml}$ of ctenophores. Ctenophore live volume was $71.6 \mathrm{ml} \mathrm{m}^{-3}$. Preserved in the sample were 4 scyphomedusae and 205 ctenophores, equivalent to 2.3 ctenophores $\mathrm{m}^{-3}$. Ctenophores collected in August were much larger than in June (Fig. 2). Live volume calculated from preserved tentacle bulb lengths was $2.3 \%$ greater than that measured directly.

Discussion. Tentacle bulbs of the lobate ctenophore Mnemiopsis leidyi provide a direct measure of number and size of the ctenophores in formalin-preserved plankton samples. This method is more accurate and more convenient than previous methods, which all require immediate sorting and handling of live specimens, and are especially difficult for small ctenophores. Data on tentacle bulb size can be converted to ctenophore biomass in wet weight (herein) or to other units. Kremer \& Nixon (1976) give formulas to convert from volume to wet weight and from wet weight to dry weight for $M$. leidyi.

I suggest the following protocol for the quantitative sampling of Mnemiopsis spp. ctenophores. (1) In order to minimize destruction of the ctenophores during collection, a plankton net with a large cod end is preferred (Reeve 1981), and the net tows should be of short duration. (2) The total live displacement volume of ctenophores in each plankton tow should be measured. This eliminates the need to calculate from preserved tentacle bulb lengths back to live volume, and provides straightforward comparisons with earlier studies (Table 1). (3) The entire sample of ctenophores should be preserved (final concentration of $5 \%$ formaldehyde). The number and sizes of the preserved ctenophore tentacle bulbs are measured using a dissecting microscope fitted with an ocular micrometer. (4) A few ctenophores over a range of sizes should be measured (volume or wet weight) and individually preserved for each sampling effort, to ensure accurate calculation from preserved tentacle bulb lengths to live volumes. These specimens provide calibration for possible differences in shrinkage of the tentacle bulbs depending on salinity, formalin concentration, temperature, or duration of sample storage. Hay (1982) found salinity and formalin concentrations to have the greatest effects on fixation shrinkage of herring larvae. Shrinkage of some preserved gelatinous zooplankters increased with the length of time in storage (Möller 1980, Yip 1982, Larson 1985).
Tentacle bulbs were used to quantify abundance and biomass of the lobate ctenophore Mnemiopsis leidyi from preserved plankton samples. The bulbs also can be recognized in the preserved gut contents of predators of M. leidyi (Purcell pers. obs.). Such methods may be applicable to other ctenophore species that retain tentacle bulbs in the adult form, and that were considered to be unquantifiable from plankton samples.

Acknowledgements. I thank F. Cresswell and L. Hill for assistance in the laboratory, and F. Cresswell, J. White, and the crew of the 'Aquarius' for assistance in the field. Shiptime was provided under grant \#NA84-AA-D-00014 to T. C. Malone from the University of Maryland Sea Grant Program of NOAA. Part of the research was supported by NSF grant \#OCE8614201 (Biological Oceanography) to J. E. Purcell. UMCEES Contribution No. 1902.

\section{LITERATURE CITED}

Adams, H. R., Flerchinger, A. P., Steedman, H. F. (1976). Ctenophora fixation and preservation. In: Steedman, H. F. (ed.) Zooplankton fixation and preservation. The UNESCO Press, Paris, p. 270-271

Burrell, V. G. Jr (1968). The ecological significance of a ctenophore, Mnemiopsis leidyi (A. Agassiz) in a fish nursery ground. M.S. thesis, Dept Biology, College of William \& Mary, Williamsburg, Va.

Burrell, V. G. Jr., Van Engel, W. A. (1970). A means of coping with Mnemiopsis leidyi in plankton samples. Chesapeake Sci. 2: $139-140$

Burrell, V G. Jr., Van Engel, W. A. (1976). Predation by and distribution of a ctenophore, Mnemiopsis leidyi A Agassiz, in the York River estuary. Estuar. coast. mar Sci. 4: 235-242

Deason, E. E. (1982). Mnemiopsis leidyi (Ctenophora) in Narragansett Bay, 1975-79: abundance, size composition and estimation of grazing. Estuar. coast. Shelf Sci. 15: $121-134$

Deason, E. E., Smayda, T. J. (1982). Ctenophore-zooplanktonphytoplankton interactions in Narragansett Bay, Rhode Island, USA, during 1972-1977. J. Plankton Res. 4: 203-217

Feigenbaum, D., Kelly, M. (1984). Changes in the lower Chesapeake Bay food chain in presence of the sea nettle Chrysaora quinquecirrha (Scyphomedusa). Mar. Ecol. Prog. Ser. 19: 39-47

Harbison, G. R., Madin, L. P., Swanberg, N. R. (1978). On the natural history and distribution of oceanic ctenophores. Deep Sea Res. 25: 233-256

Hay, D. E. (1982). Fixation shrinkage of herring: effects of salinity, formalin concentration, and other factors. Can. J. Fish. aquat. Sci. 39: 1138-1143

Heinle, D. R. (1965). A screen for excluding jellyfish and ctenophores from Clarke-Bumpus plankton samples. Chesapeake Sci. 6: 231-232

Heinle, D. R. (1974). An alternate grazing hypothesis for the Patuxent estuary. Chesapeake Sci. 15: 146-150

Herman, S. S., Mihursky, J. A., McErlean, A. J. (1967). Hallowing Point Station data report No. 5: Cooperative zooplankton investigation in the Patuxent River Estuary during the period July 1963 to February 1965. University of Maryland Natural Resources Institute Ref. No. 67-59 
Herman, S. S., Mihursky, J. A., McErlean, A. J. (1968). Zooplankton and environmental characteristics of the Patuxent River estuary 1963-1965. Chesapeake Sci. 9: 67-82

Hyman, L. H. (1940). The invertebrates: Protozoa through Ctenophora. McGraw-Hill Book Co., New York

Kremer, P. (1976). Population dynamics and ecological energetics of a pulsed zooplankton predator, the ctenophore Mnemiopsis leidyi. In: Wiley, M. L. (ed.) Estuarine processes, Vol. 1. Academic Press, New York, p. 197-215

Kremer, P. (1979). Predation by the ctenophore Mnemiopsis leidyi in Narragansett Bay, Rhode Island. Estuaries 2: $97-105$

Kremer, P., Nixon, S. (1976). Distribution and abundance of the ctenophore Mnemiopsis leidyi in Narragansett Bay. Estuar. coast. mar. Sci, 4: 627-639

Larson, R. J. (1985). Trophic ecology of gelatinous predators (Cnidaria \& Ctenophora) in Saanich Inlet, Vancouver Is., B.C., Canada. Ph.D. thesis, University of Victoria, Victoria

Le Blanc, L., Straw, T. (1972). The development of a ctenometer, a device to count luminescent animals. Sea Grant Rept. Dept. Ocean Engineering, Univ. Rhode Island, Kingston

Lonsdale, D. J. (1981). Regulatory role of physical factors and predation for two Chesapeake Bay copepod species. Mar. Ecol. Prog. Ser. 5: 341-351

Miller, R. J. (1970). Distribution and energetics of an estuarine population of the ctenophore Mnemiopsis leidyi. Ph.D. thesis, North Carolina State University, Raleigh
Miller, R. J. (1974). Distribution and biomass of an estuarine ctenophore population, Mnemiopsis leidyi (A. Agassiz). Chesapeake Sci. 15: 1-8

Miller, R. J., Williams, R. B. (1972). Energy requirements and food supplies of ctenophores and jellyfish in the Patuxent River estuary. Chesapeake Sci. 13: 328-331

Möller, H. (1980). Population dynamics of Aurelia aurita medusae in Kiel Bight, Germany (FRG). Mar. Biol. 60: $123-128$

Mountford, K. (1980). Occurrence and predation by Mnemiopsis leidyi in Barnegat Bay, New Jersey. Estuar. coast. mar. Sci. 10: 393-402

Nelson, T. (1925). On the occurrence and food habits of ctenophores in New Jersey inland coastal waters. Biol. Bull. mar. biol. Lab, Woods Hole 48: 92-111

Reeve, M. R. (1981). Large cod-end reservoirs as an aid to the live collection of delicate zooplankton. Limnol. Oceanogr. 26: $577-580$

Reeve, M. R., Baker, L. D. (1975). Production of two planktonic camivores (chaetognath and ctenophore) in south Florida inshore waters. Fish. Bull. U.S. 73: 238-248

Yip, S. Y. (1982). A note on the effect of preserving ctenophores in formaldehyde-seawater. Ir. Nat. J. 20: 416-419

Zeigenfuss, R. K., Cronin, L. E. (1958). The distribution of ctenophores in the Patuxent estuary during the summer of 1958. Md Dept of Research and Education Ref. No. 58-55

This note was presented by Dr D. K. Stoecker; it was accepted for printing on March 30, 1988 